\title{
1 Neogene to Quaternary clay mineral fluxes in the Central Indian basin
}

Pierre Debrabant ${ }^{\text {a }}$, Nathalie Fagel ${ }^{\text {a }}$, Hervé Chamley ${ }^{\text {a }}$, Viviane Bout ${ }^{\text {a }}$ and Jean-Pierre Caulet

${ }^{\text {a} S e ́ d i m e n t o l o g i e, ~ U R A ~ 719, ~ U n i v e r s i t e ́ ~ d e ~ L i l l e ~ L ~} 59655$ Villeneuve d'Ascq cedex, France

$6{ }^{\mathrm{b}}$ Géologie, URA 723, Muséum National d'Histoire Naturelle, 43, rue Buffon, 75005 Paris,

7 France

\section{Abstract}

The late Cenozoic clay sedimentation in the Central Indian Basin was investigated by mineralogical analyses of five very long cores (33-49 m long), which were recovered between $1^{\circ}$ and $10^{\circ} \mathrm{S}$ along a transect at about $80^{\circ} \mathrm{E}$ and compared with data from adjacent ODP and piston cores. Progressive changes occur from North to South, and are especially marked by a decrease of illite and chlorite amounts balanced by increased contents of smectite and kaolinite. These changes are attributed to a southwards reduction of Himalaya-derived detrital fluxes, and to a correlative augmentation both of smectite reworked from coastal Indian, Indonesian and volcanic submarine sources, and of kaolinite supplied from Australia and blocked by the equatorial divergence. The stratigraphic changes are more diversified than the geographic changes and develop discontinuously. High fluxes of illitic and chloritic materials during the middle-late Miocene reflect major activity of the Himalayan Main Central Thrust. A tectonic relaxation developed during the latest Miocene-early Pliocene, allowing alternating supply of illite-rich and smectite-rich sediments, which suggests periodical changes from distant to more local supply partly controlled by climate and by Indian intraplate deformations. The more abundant and constant amounts of smectite in late Pliocene-early Pleistocene sediments are chiefly attributed to erosion of Indian coastal zones favored by a worldwide sea-level drop. The middle to late Quaternary increase of the illite group resulted from the resumption of the tectonic activity in the Himalaya-Tibet range associated with a general climatic cooling.

\section{Introduction}

The question of the nature and origin of fine-grained minerals in the clay-rich sediments which constitute the major deposits of the Indian Ocean has been debated since the late sixties. The first syntheses were devoted to the general distribution of the main clay 
1 mineral groups, and provided preliminary arguments on their sources and genetic processes

2 (eg., Gorbunova, 1966; Griffin et al., 1968; Goldberg and Griffin, 1970; Aoki and Sudo, 3 1973; Kolla and Biscaye, 1973). Illite, chlorite and kaolinite were mostly attributed to detrital 4 supply, whereas smectite was supposed to mainly derive from submarine volcanic activity. Palygorskite, which was recorded especially in the Western Indian Ocean, was considered to result essentially from aeolian supply (Kolla et al., 1976).

Subsequent investigations were essentially performed during the eighties and combined mineralogical, geochemical and electron microscopic data in order to better characterize the origin of clay minerals, especially in the Northern Indian Ocean (eg., Fr6hlich, 1982; Tlig and Steinberg, 1982; Rao and Nath, 1988; Bouquillon et al., 1989, 1990; in Chamley, 1989; Nath et al., 1989; Brass and Raman, 1990). Special attention was paid to the nature and chemical characters of smectitic minerals, which appeared to be diversified and to result from several sources and processes. For instance Rao and Nath (1988) identified in sediments from manganese nodule fields two smectite minerals, i.e. a montmorillonite probably reworked from volcanic areas and a Fe-smectite attributed to an in situ formation in the metal-rich environment. Bouquillon et al. (1989) showed, from a multidisciplinary study of 400 samples from the northeastern Indian Ocean compared with data from continental India, that smectites are of various types (A1-Fe, AI, Fe, Si-Fe, Na-types) and mostly inherited from exposed land masses; only Si-Fe smectites and oxides seem to have been formed in their host sediments. Nath et al. $(1989,1992)$ found evidence of terrigenous influence in deep-sea sediments up to $8^{\circ} \mathrm{S}$ in the Central Indian Basin, and recognized obvious terrigenous signals among several rare-earth element (REE) patterns. Similarly Pattan and Banakar (1993) recognized from REE investigations that alumino-silicates in buried Mn nodules were of detrital origin as far as $14^{\circ} \mathrm{S}$ and $74^{\circ} \mathrm{E}$.

As clay minerals in the northern Indian Ocean are proved to derive often from a detrital origin, their variations in space and time may be used to identify the mineral sources and the paleoenvironmental controls on the distribution of fine-grained sediments. In addition the N-S replacement from continental to pelagic and chemical influences allows to investigate the characteristics of a major transitional sedimentary environment. As the northern Indian Ocean was submitted since the early Cenozoic to major changes in the tectonic context, the marine circulation, the climate and the sediment supply (in Kennett, 1982), it constitutes a working area of an outstanding interest. The mineralogical distribution of clay assemblages is able to provide much information, as already shown by many investigations performed on surface and piston core sediments. Our purpose is to investigate a much larger time interval 
1 than in previous studies, by considering the clay mineral data from sedimentary columns encompassing most of late Neogene and Pleistocene periods.

\section{Materials and methods}

During the MD 90/SHIVA cruise of the Marion- Dufresne conducted by the Geology Department of the "Museum National d'Histoire Naturelle" (Paris), five piston cores (33-49 m long) were recovered along a N-S transect (from 1 to $10^{\circ} \mathrm{S}$ ) at about $80^{\circ}$ East in the Central Indian Ocean (Fig. 1, Table 1), at water-depths ranging from 4.8 to $5.4 \mathrm{~km}$, i.e. below the modern carbonate compensation depth. The five very long cores bottomed in late Miocene to late Pliocene deposits (Caulet, 1992). In order to extend the N-S transect from the Equator to $12.5^{\circ} \mathrm{S}$, two additional cores of MD cruise 81 (Bout, 1991) and Hole $717 \mathrm{C}$ of ODP Leg 116 (Cochran, Stow et al., 1989c) have also been considered (Table 1).

The five very long MD90 cores have been lithostratigraphically described visually and by microscopic techniques. Biostratigraphic information was provided essentially by means of radiolarian assemblages (Caulet, 1992; Sanfilippo et al., 1985; Johnson et al., 1989). The nature and origin of the organic matter have been investigated on selected samples with RockEval and Leco equipments (Bout, 1991).

The mineralogical investigations have been performed on about six hundred sediments sampled every $30-40 \mathrm{~cm}$. The clay-mineral data were obtained using X-ray diffraction of the $<2 \mu \mathrm{m}$ size carbonate-free fraction (XRD). Samples were decalcified with $0.2 \mathrm{~N} \mathrm{HC1}$, and the $<2 \mu \mathrm{m}$ fraction was separated by settling. Oriented mounts were prepared on glass slides and were scanned three times $\left(\mathrm{Cu}, \mathrm{K}\right.$, radiation): from $2.5^{\circ}$ to $28.5^{\circ}$ theta on untreated samples, from $2.5^{\circ}$ to $14.5^{\circ} 2$ theta on glycolated samples, and from $2.5^{\circ}$ to $14.5^{\circ} 2$ théta on samples heated for $2 \mathrm{hr}$ at $490^{\circ} \mathrm{C}$. Analytical techniques, determination, and quantitative estimation of clay minerals are detailed in Holtzapffel (1985). Analytical uncertainties in the clay-mineral abundances are $\pm 5 \%$ (absolute) for abundances above $20 \%,+3 \%$ (absolute) for abundances between $5 \%$ and $20 \%$, and $\pm 2 \%$ (absolute) for abundances below $5 \%$.

\section{Results}

\section{Lithology}

The dominant lithologies in MD 90/SHIVA cores consist of light brown, oxidized, siliceous clayey mud superimposed to green-blackish, reduced, silty to sandy mud (Caulet, 1992). The dark color is due to organic matter (eg., 1.2-1.7\% total organic carbon in core 943), of essentially terrigenous origin (Bout, 1991; see also Cochran, Stow et al., 1989b). The 
1 sediment is statistically enriched in pelagic, biosiliceous and fine clayey components from

2 North to South and from the base to the top of the cores, (Figs. 2-4). On average the transition 3 from underlying reduced facies to super imposed oxidized facies (i.e., redox boundary) is 4 Pleistocene in age close to the equator (core 947, Fig. 3), and early Pliocene South to $6^{\circ} \mathrm{S}$ (Fig. 2). Precise correlations do not exist between the age of the redox boundary and either the latitudinal location, the thickness of the deposits or the appearance and development of biosiliceous component s (Fig. 2). The transition from reduced to oxidized bot tom conditions therefore resulted from other causes than distance from sources, sedimentation rate or marine productivity.

The three southern cores $\left(10-6^{\circ} \mathrm{S}\right)$ display very similar lithologic facies (Fig. 2). Their lower parts, late Miocene to early Pliocene in age (944:31-40.2 m, 4.9-6.3 Ma; 943:29.3-44 $\mathrm{m},<5->6.3 \mathrm{Ma} ; 942: 37.03-47.90 \mathrm{~m},>5 \mathrm{Ma})$ consist of dark green to blackish clayey mud rich in dominantly terrigenous organic matter. From 5.1-4.9 Ma upwards occur alternating centimeter- to meter-thick levels of biosiliceous and silty-clayey muds (944:20.7-31 m, 3.8/3.9-4.9 Ma; 943:21.8-29.3 m, 4.3/4.4-5 Ma; 942:28.50-37.03 m, 3.5/3.7-5 Ma). These levels are green to black below the redox boundary, and brown above (i.e., at about 4.7 Ma in cores 942 and 944, and 3.8/3.7 Ma in core 943). The blackish lithofacies appear to frequently result from redeposition processes. The brownish levels are enriched in clayey horizons to the North, and constitute transitional facies which extend up to the end of the early Pliocene. Late Pliocene and Pleistocene sediments (944: 0-20.7 m, 0.9-3.8/3.9 Ma; 943:0-21.8 m, 0.9-4.3/4.4 Ma; 942:0-28.5 m, 0.3-3.5/3.7 Ma) essentially comprise light brown biosiliceous, clayey hemipelagites. Notice that the lithology of Pliocene-Pleistocene deposits $(0-17.5 \mathrm{~m},<0.9->4.1$ Ma) in cores MD $81374 / 375$ located at $12.5^{\circ} \mathrm{S}$ is very similar to that of contemporaneous sediments at SHIVA southern sites (Fig. 4). The sedimentation rates appear to strongly differ in the three SHIVA cores during the early Pliocene, Table 2). Pleistocene deposits are 4-5 $\mathrm{m}$ thick at Sites 944 and 943, but more than $18 \mathrm{~m}$ thick in core 942 (Fig. 2).

The lithology of core $946\left(3^{\circ} \mathrm{S}\right)$ is more homogeneous than in other cores (Fig. 3). Light brown oxidized facies occur throughout the sedimentary column, anoxic facies being restricted to the lowermost part of the core (25.6-34.3 m, > 6.3-6.5 Ma, i.e., undated greenish mud at the bottom, and one single blackish organic level at about $32 \mathrm{~m}$ depth). Clay-rich facies occur principally in late Miocene deposits (25.6-34.3 m >6.3/6.5 Ma), most other sediments being enriched in biosiliceous debris $(0-25.6 \mathrm{~m},<1-6.3 / 6.5 \mathrm{Ma})$. The sedimentation rate at site 946 is similar to that of core $942(6.5 \mathrm{~m} / \mathrm{m} . \mathrm{y}$.$) and much lower than$ 
1 in cores 943 and 944 during the early Pliocene, and similar to that of the three SHIVA 2 southern cores (4-5.5 m/m.y.) during the late Pliocene (Table 2).

Core 947 , which was recovered to the northwest of site 946 at $1.5^{\circ} \mathrm{S}$, surprisingly displays very heterogeneous and variable lithofacies (Fig. 3). Most of the $33.9 \mathrm{~m}$ thick sedimentary column corresponds to alternating greenish and blackish reducing clayey to silty muds. A few calcareous reworked facies are interbedded in the reducing sediments, and probably result from slumping on adjacent submarine highs such as the Chagos- Laccadive Rise (Cochran, 1990). Brownish oxidized, biosiliceous facies occur only in the $4 \mathrm{~m}$ deposited during the middle-late Pleistocene since $0.17 \mathrm{Ma}$. The late Pliocene and Pleistocene sedimentation rates at site 947 are much higher than at southeastern site 946 (Fig. 3).

ODP Hole $717 \mathrm{C}$, drilled during Leg 116 at $0.5^{\circ} \mathrm{S}$ and $81^{\circ} \mathrm{E}$ to the north of the SHIVA core transect in the distal part of the Ganges deep-sea fan (Fig. 1), is dominated by reworked sediments largely derived from the North (Cochran, Stow et al., 1989a). Latest Miocene (Messinian) to Pleistocene deposits are more than $500 \mathrm{~m}$ thick and mostly comprise sandy to clayey turbidites interbedded with hemipelagites (Fig. 4). The turbidites are either of light or dark gray color, and include some terrigenous organic matter. The coarsest lithofacies deposited during the middle- late Miocene and the middle-late Pleistocene, which corresponds to the highest sedimentation rates (up to $350 \mathrm{~m} / \mathrm{Ma}$ in the late Pleistocene).

\section{Clay mineralogy}

Southern sites

The cores SHIVA 942, 943 and 944 (Fig. 1) contain very similar clay assemblages in the $<2 \sim$ tm sedimentary fraction (Fig. 2). Smectite minerals constitute the dominant species (35-90\%) followed by illite (5-45\%), kaolinite (5-25\%), chlorite (0-10\%) and random mixedlayers (0-10\%, mainly of illite-smectite types). Associated non clay minerals include ubiquitous quartz and frequent feldspars, as well as occasional other species (e.g., pyrite, iron oxides).

Geographically the number and intensity of illite pulses are decreasing towards the south (Fig. 2). By contrast the average percentages of smectite and of kaolinite increase progressively southwards. The same trend extends in a larger geographic area, smectite and kaolinite amounts continuing to increase south of $10^{\circ} \mathrm{S}$ in MD 81 cores 374/375 (Fig. 4a). There is no general relationship between lithology and clay mineralogy, and the redox transition which occurs at different periods in the three cores is not associated with any durable change in clay mineral proportions. 
1 Stratigraphically, two successive clay mineral zones are recognized in late Cenozoic 2 sediments of SHIVA cores 942 to 944 (Fig. 2). From the late Miocene (ca. 6.3 M.a.) to early 3 Pliocene (3.7-3.5 Ma) strong alternations of smectite-rich and illite-rich layers occur, 4 characterizing the mineralogical zone 1. The percentages of kaolinite also fluctuate in this zone, but independently of those of the two other clay groups. This suggests distinct origins for the three main clay minerals. Notice that the illite and smectite alternations recorded in SHIVA cores from 1.5 to $10^{\circ} \mathrm{S}$ do not exist any longer more southwards, as shown by their absence in early Pliocene sediments deposited at $12.5^{\circ} \mathrm{S}$ in MD 81 cores 374 and 375 (Fig. 4a, Bout, 1991).

The mineralogical zone 1 can be divived in two subzones. Subzone la corresponds to late Miocene-earliest Pliocene series, in which the black, organic-rich, often redeposited levels correlate with higher percentages of smectite. As the organic matter is essentially of a continental nature (Bout, 1991), this suggests the dominantly terrigenous origin of the clay mineral. Subzone $l b$ corresponds to sediments progressively enriched in biosiliceous components, interbedded with silty clayey detrital pulses usually enriched in illite, chlorite and random mixed-layers. The illite group in subzone $\mathrm{lb}$ corresponds dominantly to resedimented deposits, whereas smectite-rich levels rather characterize hemipelagites. The relative amounts of the sum of illite + chlorite + random mixed-layers are higher in the mineralogical zone $\mathrm{lb}$ (late early Pliocene) compared to surrounding zones la and 2. Notice that the transition between mineralogical subzones $\mathrm{I} a$ and $1 \mathrm{~b}$ in cores 942 and 944 occurs during the early Pliocene ca. 4.9-4.7 Ma ago, at a period marked by a high sea-level stage (Haq et al., 1987). The uppermost levels of subzone 1 a are devoid of chlorite, a mineral commonly associated with illite in Himalaya-derived products (Bouquillon et al., 1989, 1990).

Mineralogical zone 2 encompasses the late Pliocene (from 3.6 m.y. ago) and Pleistocene stages. Illite-smectite alternations have disappeared and been replaced by a fairly homogeneous and constant clay mineral suite largely dominated by smectite $(70-80 \%$ of the clay fraction; Fig. 4). Smectite amounts reach maximum values in late Pliocene sediments. In the course of the Pleistocene the illite group amount increases slightly again, and is associated in core $942\left(10^{\circ} \mathrm{S}\right)$ with a moderate augmentation of kaolinite.

Equatorial sites

Average percentages of illite and chlorite are higher at northern locations than at southern sites, whereas those of smectite and kaolinite are lower. Respectively located at $3^{\circ}$ 
1 and $1.5^{\circ} \mathrm{S}$, the cores SHIVA 946 and 947 display different clay mineral zonations (Fig. 3).

2 Core $946\left(78^{\circ} \mathrm{E}\right)$, which consists almost exclusively of oxidized lithofacies, comprises the 3 mineralogical zones 1 (alternating illite-rich and smectite-rich levels) and 2 (more constant smectite-rich deposits) which have already been recognized at southern sites 942 to 944 (Fig. 2). The transition between zones 1 and 2 occurs in the middle part of a lithologic unit composed of biosiliceous clayey muds, stressing the absence of any close correspondence between lithology and clay mineralogy. The boundary is located close to the early Pliocenelate Pliocene passage. Zone 1 can be divided in two subzones la and $\mathrm{lb}$ as in cores to the South, the boundary being located at the transition from greenish reducing clayey muds to brownish oxidized biosiliceous muds. In addition it is possible to identify a mineralogical zone 3 in the upper $4 \mathrm{~m}$ (Pleistocene) of core 946, which is marked by significantly increased amounts of illite and chlorite.

Core $947\left(76^{\circ} \mathrm{E}\right)$, which essentially comprises reducing lithofacies, is marked by an unusual extension of mineralogical zone 1 (Fig. 3). Smectite-rich levels and sediments enriched in illite, chlorite and often kaolinite alternate throughout this $34.4 \mathrm{~m}$ long core. Only the uppermost $3 \mathrm{~m}$ of Pleistocene sediments display oxidized facies marked by more homogeneous clay assemblages, which are referred to as mineralogical zone 2 . A total of $75 \%$ of the dark levels containing organic matter of a dominant continental origin are enriched in smectite, supporting the mainly terrigenous origin of the clay mineral. A few calcareous turbidites rich in illite suggest reworking from submarine highs. For example since the Middle Miocene the bioclastic turbidites from the Chagos-Laccadive aseismic ridge are enriched in primary minerals from the Indus discharge (Weser, 1974; DSDP Leg 23, Site 219).

Hole 717C of ODP Leg 116 is located northeast of cores 946 and 947 and very close to the equator (Fig. 1) and shows an amplification of the mineralogical changes recorded at the SHIVA cores (Bouquillon et al., 1990; Brass and Raman, 1990). The average contents of Himalaya-derived clay minerals (illite and chlorite) display both very high values (up to $80 \%$ of the clay minerals) and strong temporal variations (Fig. 4b). Despite these differences with SHIVA core data, a similar zonation can be established. After middle to late Miocene strong fluxes of illite and chlorite attributed to intense tectonic activity in the Himalaya-Tibet range (Bouquillon et al., 1990; Aoki et al., 1991), the latest Miocene-early Pliocene shows alternating smectite/organic matter-rich and illite-rich levels which resemble mineralogical zone 1. Late Pliocene to early Pleistocene deposits contain more constant and often smectite- 
1 illite group is recorded from mineralogical zones 1 to 2 when moving from southern site MD

2946 to the northern site ODP 717. The middle to late Pleistocene sediments display a further 3 strong increase of the illite group which resembles with much more intensity the 4 mineralogical zone 3 identified in core 946 (Fig. 3). Notice that the kaolinite percentage increases at Site 717 relative to southern sites, suggesting that this mineral here results from sources located around the northern part of the Indian Ocean. The quantitative variations of kaolinite often parallel those of smectite and are in opposition with illite and chlorite percentages (Fig. 4b).

\section{Discussion}

Major clay mineral sources and distribution

In the Central Indian Basin the amounts of illite, chlorite and random mixed-layers as well as the number of illite pulses increase to the north throughout the late Cenozoic and reach maximum values in the Bengal deep-sea fan where Ganges/Brahmaputra derived channels feed directly the marine sedimentation. Numerous references document the high abundance of these minerals in the Himalaya-Tibet mountain range (metamorphic and magmatic rocks) and their river drainage systems (e.g. in Bouquillon et al., 1989, 1990; Chamley, 1989; Brass and Raman, 1990; Raman et al., 1993). As a consequence the main modern source of illite, chlorite and associated random mixed-layers (three minerals referred to as the "illite group") is located to the north of the Indian Ocean in Himalayan chains. The southwards decrease of the abundance of these minerals reflects their dispersion among plankton-derived components and fine mineral particles derived from other sources. The Himalayan influences, which are clearly recorded as far as $10^{\circ} \mathrm{S}$ (core 942 , Fig. 2), especially by repeated fluxes of the illite group in late Miocene-early Pliocene deposits (see also Nath et al., 1989), are lacking beyond this latitude in cores 374/375 (Fig. 4, a) suggesting (1) that the equatorial divergence acted during this period as a barrier against northern terrigenous inputs or (2) an ultimate stage of dilution.

Contrary to the illite group, the kaolinite amount tends to increase significantly towards the south (Fig. 4), suggesting distant terrigenous sources located southeast of the Central Indian Basin. The most probable source of kaolinite lies in the soils and rocks of Western Australia which are eroded by westwards winds, as documented in Pye (1987) (see also Bouquillon et al., 1989; Chamley, 1989). The particularly high amounts of kaolinite (up to $25 \%)$ in SHIVA cores $942\left(10^{\circ} \mathrm{S}\right)$ and $374 / 375\left(12.5^{\circ} \mathrm{S}\right)$, relative to the more northern cores (SHIVA 943-947. Fig. 3), could reflect the role of an oceanic barrier played by the equatorial 
1 divergence relative to the transportation of clay minerals towards the north (see Fig. 6).

2 Notice that the fairly high amounts of kaolinite in ODP Hole 717c sediments drilled in the

3 Ganges deep-sea fan result from other sources (Indogangetic plain and eastern coast of India,

4 Sri Lanka (Bouquillon et al., 1989)) which are close to those of smectite, since kaolinite fluctuations mostly parallel smectite variations (Figs. 4, 6, 7).

As documented by previous investigations, smectite minerals in Northern Indian Ocean sediments largely result from detrital supply and transportation (see Introduction section). Sources of smectite are diversified and vary according to the chemical nature of the mineral (e.g., Bouquillon et al., 1989). In the Central Indian Basin a terrigenous origin for a large part of smectite is supported by frequent increases of the mineral and associated essentially land-derived organic matter. The occurrence of smectite-rich sediments in redeposited facies (slumps, etc) corroborates such an assertion. As redeposited facies rich in smectite especially appear to occur in western cores (e.g. SHIVA 947; see also Bouquillon et al., 1989), a dominant source of smectite is supposed to be located in Southern India and Sri Lanka. The contribution of the Deccan Traps is always present (Amano et al., 1992; Aoki et al., 1991). The mineral is especially produced by weathering of Indian basalts and other rocks submitted to tropical humid climate. Smectite is known to be abundantly supplied on the eastern Indian margin from weathered rocks outcropping in India (Raman et al., 1992). Other sources consist of Indo-Gangetic plains, Indonesia and reworked products of altered submarine volcanics (Bouquillon et al., 1989). The southwards increase of smectite therefore appears to result from both a diminution of Himalaya-derived products (illite group) and an augmentation of materials from alluvial plains and volcanic areas. In addition differential settling processes tend to favor the deposition of smectite in open sea environments. The proportion of authigenic smectite in the clay assemblages of the northern part of the Central Indian Basin remains indeterminate, and this question needs further geochemical investigations.

\section{Continental control of clay mineral successions}

The very large abundance of the illite group, which is recorded at ODP Hole 717C in the middle-late Miocene (Fig. 6b) and at other ODP Leg 116 Sites since the early Miocene (Cochran, 1990), reflects a major erosion stage in the Himalayan mountain range (Fig. 6a). An uplift phase linked to major activity in the Himalayan Main Central Trust induced strong continental erosion and rapid growth of the Ganges deep-sea fan (Gansser, 1966; Curray and Moore, 1971), development of turbidite facies (Stow et al., 1990), and high fluxes of sand- 
1 sized feldspars and micas (Copeland et al., 1990). The clay mineral expression of this major 2 step of Himalayan collision consists in abundant illite and chlorite supply in the Central

During the upper part of late Miocene and the early Pliocene the fluxes of Himalayaderived illite group still remained important but diminished in abundance and alternated with smectite inputs (mineralogical zone 1; Figs. 2, 3, 4). The decrease of illite and chlorite supply reflects a relaxation stage of the Himalayan tectonic activity (Gansser, 1966). As smectite is often associated with redeposited lithofacies and land-derived organic matter, it is considered to frequently result from the supply to the ocean of soil-derived materials. Terrigenous smectite is a mineral primarily formed in soils of the downstream zones of river basin systems under warm climate (in Chamley, 1989). Kaolinite, which is often associated with smectite detrital discharges, especially at ODP Site 717 (Fig. 4b), supports the hypothesis of soilderived mineral fluxes. The decrease of tectonic activity during the latest Miocene-early Pliocene therefore allowed clay assemblages to express the tropical climatic conditions which characterized the Indian subcontinent. The abundance of detrital smectite around southern India and Sri Lanka (Bouquillon et al., 1989; Raman et al., 1992), and the northwestern origin of smectite-bearing slumps and turbidites at ODP Sites drilled in the Ganges distal deep-sea fan (Stow et al., 1990; Sager and Stuart, 1990), suggest that smectite inputs largely derive from eastern and southern Indian land masses (Fig. 6b). According to Aoki et al. (1991), the dioctahedral Fe-beidellite in the ODP Leg 116 originated largely from the augite-basalt on the Indian Deccan Traps. As a consequence the clay sedimentation in the northern part of the Central Indian Basin at the Miocene-Pliocene transition is mainly attributed to alternating, aperiodic, detrital fluxes issuing from the North (Himalayan range) and from the West (South India). Additional illitic inputs could have been determined by the lateral migration of feeding channels of the deep-sea fan (Yokohama et al., 1990). In the southernmost part of the study area beyond $10^{\circ} \mathrm{S}$ the illite/smectite alternations are no longer identified, which probably results from both the dilution of north-derived detrital fluxes in the pelagic biosiliceous sedimentation, and the role of barrier to northern supply played by the equatorial divergence (Fieux, 1987). Notice that current high-resolution investigations suggest that decimetric, second-order illite/smectite fluctuations are controlled by earth's orbital cycles (N. Fagel, pers.comm., 1992).

The late Pliocene-early Pleistocene period (Fig. 6c), which is marked in most cores by more abundant and more constant amounts of smectite in the clay sedimentation (mineralogical zone 2), corresponds to strong sea-level fluctuations resulting in a global drop 
1 (Prell, 1982; Zimmerman et al., 1984; Haq et al., 1987). These sea level fluctuations favored 2 the active erosion of coastal soils and sedimentary materials accumulated on the shelf, and primarily the smectite-rich soils and sediments of Southern India and Sri Lanka regions which are closest to the study area (Bouquillon et al., 1989; Raman et al., 1992). Such reworking of coastal pedogenic and shelf sedimentary materials is consistent with the association in deepsea deposits of smectite (and partly of kaolinite) with land-derived organic matter and with nannofossil shells reworked from the western upper margin (Stow et al., 1990). Of course smectites were also eroded from other coastal regions surrounding the Gulf of Bengal (IndoGangetic plain, Indonesia, submarine volcanic highs; Fig. 5), which is expressed by differences in the particular chemical composition of this mineral group in the Northeastern Indian Ocean (in Bouquillon et al., 1989, 1990).

The middle-late Pleistocene corresponds, from about $0.8 \mathrm{Ma}$ ago, to increasing supply of illite and chlorite minerals, particularly in cores located to the north of the study area (MD 946 and 947, ODP 717C. Figs. 3, 4). This mineralogical change correlates with a resumption of activity along the Main Central Thrust in the Himalayan range. The illitic flux reflects this important tectonic activity (Aoki et al., 1991; Fig. 6d), as does the intense turbidite deposition in the Ganges deep-sea fan (Gansser, 1966; Stow et al., 1990). Sea-level drops related to global climatic cooling (Pisias and Moore, 1981) during Pleistocene times favored the direct erosion of rock-derived products relative to soil-derived products (in Chamley, 1989), which still increased the supply to the ocean of illite and chlorite. The absence of significant clay mineral changes at this time in the southernmost cores (e.g. SHIVA 942, Fig. 2) is somewhat surprising, and suggests that a submarine oceanic circulation control of the clay sedimentation partly obliterated the continental control.

\section{Submarine control of clay mineral successions}

In addition to the sedimentary formation of autochthonous smectite (especially Fesmectite associated with iron-oxides), which is supposed by several authors (e.g., Fr6hlich, 1982; Bouquillon et al., 1989; Rao and Nath, 1988; Nath et al., 1989) but is still unquantified, the distribution of clay mineral assemblages in the Central Indian Basin appears to partly depend on submarine circulation processes. As already stated above, the equatorial divergence seems to have played an essential role in the dilution of clay particles among the siliceous planktonic remains, in impeding the southwards transfer of Himalaya-derived 
1 minerals (e.g., kaolinite). It allows also lateral mineral transportations through its migration in

2 the course of the time (see Discussion section: mineral sources and distribution).

Some other lithological and clay mineralogical features in the Central Indian Basin appear to depend on morphological and tectonical characteristics. The progressive replacement of anoxic facies by oxidized facies, which takes place at different periods according to the core location and is neither related to the development of biosiliceous facies nor to the clay mineral composition, sets up an intriguing problem. The major lithological changes seem to strongly depend on the intraplate deformations which affected the Northern Indian Ocean because of the India-Asia collision processes (Sclater and Fisher, 1974; Weissel et al., 1980; Geller et al., 1983; Stein et al., 1989; Cochran, Stow et al., 1989c; Karner and Weissel, 1990; Leger and Louden, 1990). For instance the early development (late Mioceneearly Pliocene) of oxidized lithofacies in core SHIVA 946, opposed to their very late appearance (middle Pleistocene) in core 947 probably resulted from the location of the two cores on either side of a submarine relief. Such a submarine high could have favored oxidation and low sedimentation at the eastern site, and active, organic- and turbidite-rich sedimentation at the western site. The abundance and strong variations of the Himalayaderived illite group at site SHIVA 947 probably resulted from the same cause, feeding channels of the Ganges deep-sea fan running preferentially through Site 947 area. A similar explanation has been put forward to explain the very different sedimentation rates recorded during the Pliocene at ODP Sites 717 and 718 (Table 2), which are located only $10 \mathrm{~km}$ apart in an area of active faults and tilted blocks (Cochran, 1990).

The deformation due to the Indian intraplate compression also favored structural instability and earthquakes on the continental margins, responsible for turbiditic currents and slumpings into the adjacent oceanic basins. Such sediment reworking developed especially on the eastern India margin and on the flanks of submarine highs (Stow et al., 1990). The fluxes of smectite-rich sediments, which are particularly developed in the easternmost SHIVA core 947 located at the foot of the Chagos-Laccadive rise, could result from such gravity flows controlled by plate compression (Fig. 7). Finally one should notice that the clay mineral associations are very similar from late Miocene to Pleistocene times in SHIVA cores 942, 943 and 944, which are located on a unique structural block bordered by Indrani and Indira fracture zones (Fig. 7). This similarity also suggests a regionally developing structural control of the clay sedimentation.

\section{Conclusion}


(1) Mineralogical, lithological and biostratigraphical investigations on five very long cores recovered along a $80^{\circ} \mathrm{E}$ transect in the northern part of the Central Indian Basin, compared with data from previous studies, allow to clarify the different factors controlling the clay sedimentation since the late Miocene. The geographic and stratigraphic distribution of clay mineral associations depend on both continental and oceanic environmental factors.

(2) The clay mineral sources are located in both continental and submarine domains. Most minerals are reworked from land, continental margins or aseismic ridges. The amount of authigenic minerals and especially of smectitic minerals is still unknown, but does not seem to be dominant as stated by the close correlation recorded between smectite contents and essentially terrigenous organic matter pulses. Illite, chlorite and random mixed-layers come essentially from the Himalaya-Tibet range, through the river systems and the Ganges deep-sea fan tributaries. Kaolinite is dominantly supplied from Australia by aeolian and marine current, and accessorily from southern India through soil erosion. Smectite is abundantly reworked from weathering profiles developed on southern India basalts and other rocks, as well as from the upper continental margin of eastern India and Sri Lanka. Additional smectite is supplied from the Indo-Gangetic plain, Indonesia and submarine volcanic areas.

(3) The Himalayan tectonic activity is responsible for two major inputs of the illite group in the marine clay sedimentation, first during the early to late Miocene, and secondly since the middle Pleistocene. These inputs, which induced the obliteration of other paleoenvironmental messages born by clay assemblages, were determined by renewed erosion of the mountain range due to activation of the Main Central Thrust. In addition to continental tectonics in Asia, Indian Ocean intraplate movements resulted during the late Cenozoic in important local changes in the redox budget, the sedimentation rates and illitic fluxes, as well as in discharges of smectite- and organic matter-bearing sediments reworked during the late Miocene-early Pliocene from eastern India margins and submarine highs.

(4) The expression by clay assemblages of continental climate is expressed only during tectonic relaxation stages, especially in late Pliocene-early Pleistocene times where abundant smectite associated with kaolinite reflects the tropical-humid conditions responsible for active chemical weathering in South India.

(5) The clay mineral sedimentation reflects the sea-water movements in two ways. The sea-level drops developing since the late Pliocene globally favored the reworking of smectite accumulated in coastal soils and on the upper par $t$ of continental margins. Furthermore the equatorial divergence acted regionally at different latitudes according to the period as a hydro 
1 dynamical barrier against the transfer to the south or to the north of suspended minerals, and

2 induced the mixture in the sediments of land-derived minerals and plankton-derived siliceous 3 biogenics.

(6) High-resolution mineralogical and geochemical investigations currently per formed should help in answering some unsolved questions such as the quantification of authigenically formed smectite, precise petrographic sources of clay minerals, and earth's orbital control on late Cenozoic clay sedimentation.

\section{Acknowledgments}

The technical support of the investigations was provided by M. Bocquet, J. Carpentier, F. Dujardin and P. Récourt. We are very indebted to S. Aoki, P. De Deckker and C. Robert for their helpful review. This study was founded by CNRSINSU Program DBT, Message Sédimentaire, Grant 1991-1992.

\section{References}

Amano, K. and Taira, A., 1992. Two-phase uplift of Higher Himalayas since 17 Ma. Geology, 20: 391-394.

Aoki, S., Kohyama, N. and Ishizuka, T., 1991. Sedimentary history and chemical characteristics of clay minerals in cores from the distal part of the Bengal Fan (ODP 116). Mar. Geol., 99: 175-185.

Aoki, S. and Sudo, T., 1973. Mineralogical study of the core samples from the Indian Ocean, with special reference to the vertical distribution of clay minerals. J. Oceanogr. Soc. Jap., 29: 87-93.

Bouquillon, A., Chamley, H. and Fr6hlich, F., 1989. Sédimentation argileuse récente dans l'Océan Indien Nord- Oriental. Oceanol. Acta, 12: 133-147.

Bouquillon, A., France-Lanord, C., Michard, A. and Tiercelin, J.-J., 1990. Sedimentology and isotopic chemistry of the Bengal Fan sediments: the denudation of the Himalaya. In: J.R. Cochran, D.A.V. Stow et al., Proc. ODP Sci. Res. 116: 43-58.

Bout, V., 1991. Flux sédimentaires argileux néogènes et quaternaires dans le Bassin Indien Central. DEA, Lille, $57 \mathrm{pp}$.

Brass, G.W. and Raman, C.V., 1990. Clay mineralogy of sediments from the Bengal Fan. In:

J.R. Cochran, D.A.V. Stow et al., Proc. ODP Sci. Res., 116: 35-42.

Caulet, J.-P., 1992. Les rapports des campagnes . la mer :à bord du "Marion-Dufresne", 
1 Chamley, H., 1989. Clay Sedimentology. Springer, Berlin, 623 pp.

2 Cochran, J.R., 1990. Himalayan uplift, sea level and the record of Bengal Fan sedimentation 3 at the O.D.P. Leg 116 sites. In: J.R. Cochran, D.A.V. Stow et al., Proc. ODP Sci. Res., 116: $4 \quad 397-416$.

5 Cochran, J.R., Stow, D.A.V. and O.D.P. Leg 116 Shipboard Scientific Party, 1989a. Intraplate

6 deformation and Bengal Fan sedimentation: Background and objectives. Proc. ODP Init. 7 Rep., 116: 3-11.

8 Cochran, J.R., Stow, D.A.V. and O.D.P. Leg 116 Shipboard Scientific Party, 1989b. Organic

9 Geochemistry. Proc. ODP Init. Rep., 116: 57-58.

10 Cochran, J.R., Stow, D.A.V. and O.D.P. Leg 116 Shipboard Scientific Party, 1989c. O.D.P.

11 Leg 116 Site Survey. Proc. ODP Init. Rep., 116: 197-210.

12 Copeland, P., Harrison, M. and Heizler, M.T., 1990. $4^{\circ} \mathrm{Ar} / 39$ Ar single-crystal dating of 13 detrital muscovite and K-Feldspar from Leg 116, Southern Bengal Fan: Implications for the 14 uplift and erosion of the Himalayas. In: J.R. Cochran, D.A.V. Stow et al., Proc. ODP Sci. 15 Res., 116: 93-116.

16 Curray, J.R. and Moore, D.G., 1971. Growth of the Bengal deep sea fan and denudation of the 17 Himalayas. Geol. Soc. Am. Bull., 82: 563-572.

Fieux, M., 1987. Conf6rence . la mémoire d'Anton Bruun: mousson et courants dans l'Oc6an Indien. In: 14ème Session de la Commission océanographique inter gouvernementale. UNESCO.

21 Fröhlich, F., 1982. Evolution min6ralogique dans les dépôts azoïques rouges de l'Océan 22 Indien. Relations avec la stratigraphie. Bull. Soc. Géol. Fr., (7) 14: 563-571. Gansser, A., 1966. The Indian Ocean and the Himalayas, a geological interpretation. Eclogae Geol. Helv., 59: 831-848.

Geller, C.A., Weissel, J.K. and Anderson, R.N., 1983. Heat transfer and intraplate deformation in the Central Indian Ocean. J. Geophys. Res., 88: 1018-1032. Gotdberg, E.D. and Griffin, J.J., 1970. The sediments of the northern Indian Ocean. Deep-Sea Res., 17: 513-537.

29 Gorbunova, Z.N., 1966. Clay mineral distribution in the Indian ocean. Okeanologiia, 6:267275 (in Russian).

31 Griffin, J.J., Windom, H. and Goldberg, E.D., 1968. The distribution of clay minerals in the world oceans. Deep-Sea Res., 15:433 459.

33 Haq, B.U., Hardenbol, J. and Vail, P.R., 1987. Chronology of fluctuating sea levels since the Triassic. Science, 235: 1156-1167. 
1 Holtzapffel, T., 1985. Les minéraux argileux. Preparation. Analyse diffractométrique et 2 détermination. M6m. Soc. Géol. Nord, Lille, 12, 136 pp.

3 Johnson, D.A., Schneider, D.A., Nigrini, C.A., Caulet, J.P. and Kent, D.V., 1989. Pliocene-

4 Pleistocene radiolarian events and magneto-stratigraphic calibrations for the tropical Indian

5 Ocean. Mar. Micropaleontol., 14: 33-66.

6 Karner, G.D. and Weissel, J.K., 1990. Compressional deformation of oceanic lithosphere in

7 the Central Indian Ocean: Why it is, Where it is. In: J.R. Cochran, D.A.V. Stow et al., Proc.

8 ODP, Sci. Res., 116:279 289.

9 Kennett, J.P., 1982. Marine Geology. Prentice Hall, Englewood Cliffs, N J, 813 pp.

Kolla, V. and Biscaye, P., 1973. Clay mineralogy and sedimentation in the Eastern Indian

11 Ocean. Deep-Sea Res., 20:727 738.

12 Kolla, V., Henderson, L. and Biscaye, P., 1976. Clay mineralogy and sedimentation in the 13 Western Indian Ocean. Deep- Sea Res., 23: 949-961.

14 Leger, G.T. and Louden, K.E., 1990. Seismic refraction measurements in the Central Indian 15 Basin: evidence for crustal thickening related to intraplate deformation. In: J.R. Cochran, 16 D.A.V. Stow et al., Proc. ODP Sci. Res., 116: 291-309.

17 Nath, B.N., Rao, V.P. and Becker, K.P., 1989. Geochemical evidence of terrigenous influence in deep-sea sediments up to $8^{\circ} \mathrm{S}$ in the Central Indian Basin. Mar. Geol., 87: 301-313. Nath, B.N., Roelandts, I., Sudhakar, M. and Pliiger, W.L., 1992. Rare earth element patterns of the Central Indian Basin sediments related to their lithology. Geophys. Res. Lett., 19: 1197-1200.

22 Pattan, J.N. and Banakar, V.K., 1993. Rare earth element distribution and behavior in the buried manganese nodules from the Central Indian Basin. Mar. Geol., 112: 303-312.

Pisias, N.G. and Moore Jr., T.C., 1981. The evolution of Pleistocene climate: A time series approach. Earth Planet, Sci. Lett., 52: 450-456.

Prell, W.L., 1982. Oxygen and carbon isotope stratigraphy for the Quaternary of hole 502B: Evidence for two modes of isotopic variability. In: W.L. Prell, J.V. Gardner et al., Init. Rep. DSDP, 68: 455-464.

Pye, K., 1987. Aeolian Dust and Dust Deposits. Academic Press, New York, 334 pp. Raman, C.V., Krishna Rao, G., Reddy, K.S.N. and Ramesh, N., 1992. Clay minerals in the continental shelf sediments, East coast of India. Cont. Shelf Res., in press. Rao, V.P. and Nath, B.N., 1988. Nature, distribution and origin of clay minerals in grain size fractions of sediments from manganese nodule field, Central Indian Ocean Basin. Indian J. 
1 Sager, W.W. and Stuart, A.H., 1990. Magnetic properties of black mud turbidites from O.D.P.

2 Leg 116, distal Bengal Fan, Indian Ocean. In: J.R. Cochran, D.A.V. Stow et al., Proc. ODP 3 Sci. Res., 116:317 336.

4 Sanfilippo, A., Westberg-Smith, M.J. and Riedel, W.R., 1985. Cenozoic Radiolaria. In: H.M.

5 Bolli, K. Perch-Nielsen and J.B. Saunders (Editor), Plankton Stratigraphy. Cambridge Univ.

6 Press, pp. 631712.

7 Sclater, J.G. and Fisher, R.L., 1974. The evolution of the East Central Indian Ocean with 8 emphasis on the tectonic setting of the Ninetyeast Ridge. Geol. Soc. Am. Bull., 85: 683-702.

9 Stein, C.A., Cloetingh, S. and Wortel, R., 1989. Seasat-derived gravity constraints on stress 10 and deformation in the Northeastern Indian Ocean. J. Geophys. Res., 83: 2233-2245.

11 Stow, D.A.V., Amano, K., Balson, P.S., Brass, G.W., Corrigan, J., Raman, C.V., Tiercelin, J.12 J., Townsend, M. and Wijayananda, N.P., 1990. Sediment facies and processes on the distal 13 Bengal Fan, Leg 116. In: J.R. Cochran, D.A.V. Stow et al., Proc. ODP, Init. Rep., 116: 37714396.

15 Tlig, S. and Steinberg, M., 1982. Distribution of rare-earth elements (REE) in size fractions of 16 recent sediments of the Indian Ocean. Chem. Geol., 37: 317-333.

17 Weissel, J.K., Anderson, R.N. and Geller, C.A., 1980. Deformation of the Indo-Australian plate. Nature, 287: 284-291.

Weser, O.E., 1974. Sedimentological aspects of strata encountered on Leg 23 in the Northern Arabian Sea. Init. Rep. DSDP, 23: 503-519.

21 Yokohama, K., Amano, K., Taira, A. and Saito, Y., 1990. Mineralogy of silts from the Bengal 22 Fan. In: J.R. Cochran, D.A.V. Stow et al., Proc. ODP, Init. Rep., 116: 59-74. Zimmerman, H.B., Shackleton, N.J., Backman, J., Kent, D.V., Baldauf, J.G., Kaltenbach, A.J. and Morton, A.C., 1984. History of Plio-Pleistocene climate in the northeastern Atlantic, Deep Sea Drilling Project Hole 552A. In: D.G. Roberts, D. Schnitker, et al., Init. Rep. DSDP, 81: 861-875. 
Figure Captions

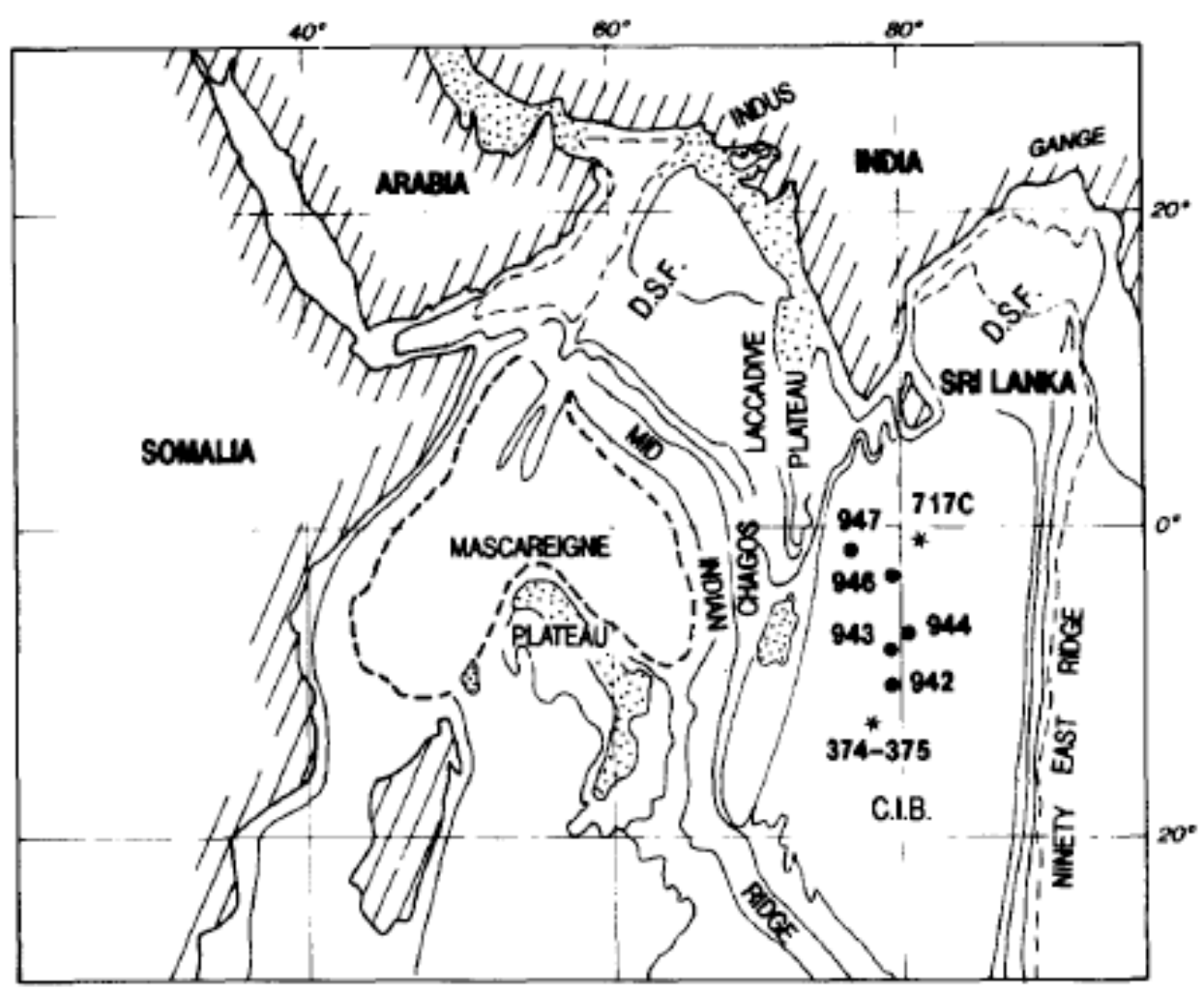

Fig. 1. Location of the five very long SHIVA cores (MD 90-942 to -947) recovered in the

4 Central Indian Basin (C.1.B.), and of reference cores. D.S.E $=$ deep-sea fans. 

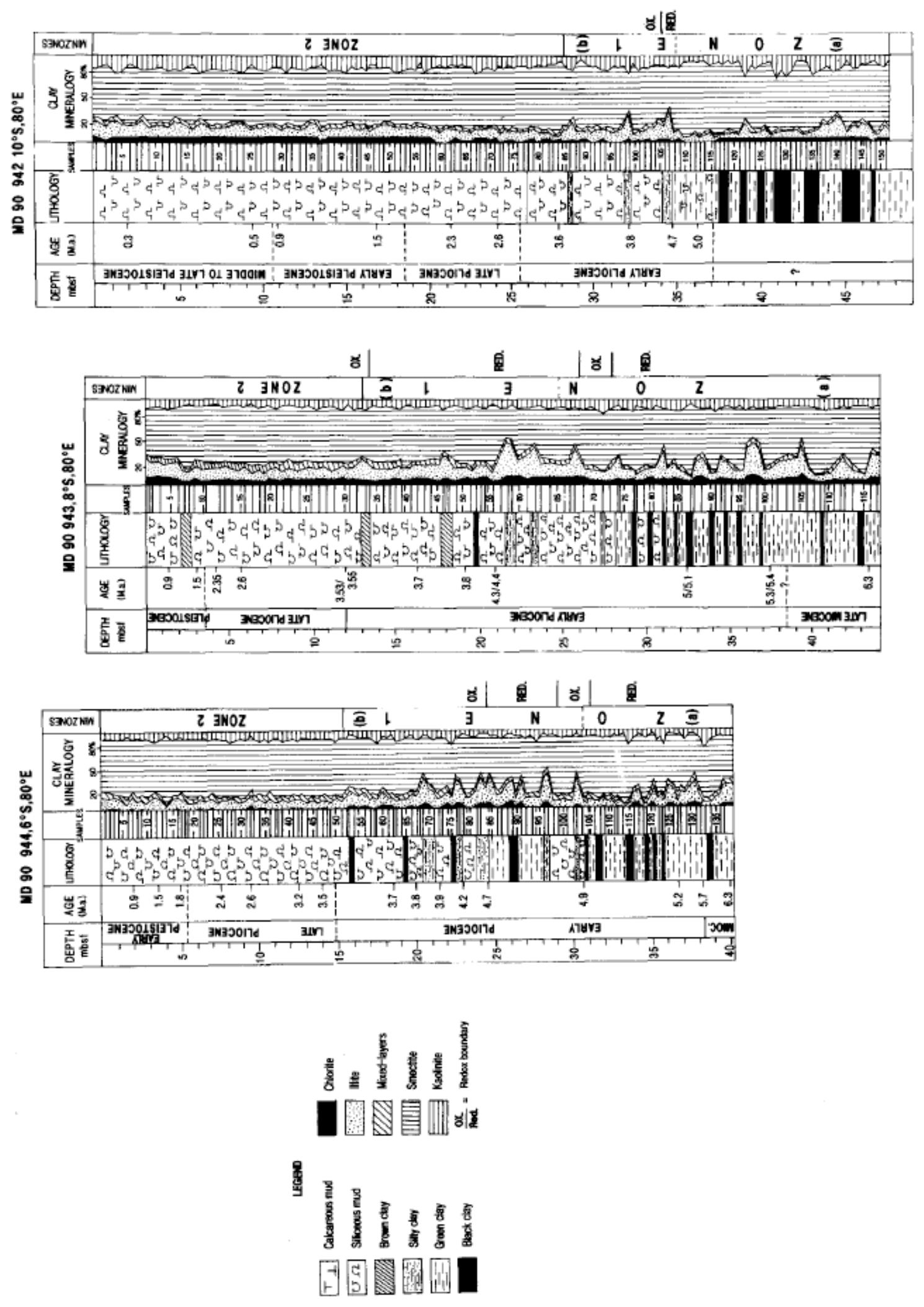

2 Fig. 2. Detailed lithology and clay mineralogy of southern SHIVA cores (MD 90-942 to -944) 3 in the Central Indian Basin between $6^{\circ}$ and $10^{\circ} \mathrm{S}$ at $80^{\circ} \mathrm{E}$. Age (in Ma) deduced from 4 radiolarian associations. Zonation from clay mineral successions. $O X . / R E D .=$ redox 5 boundary. 

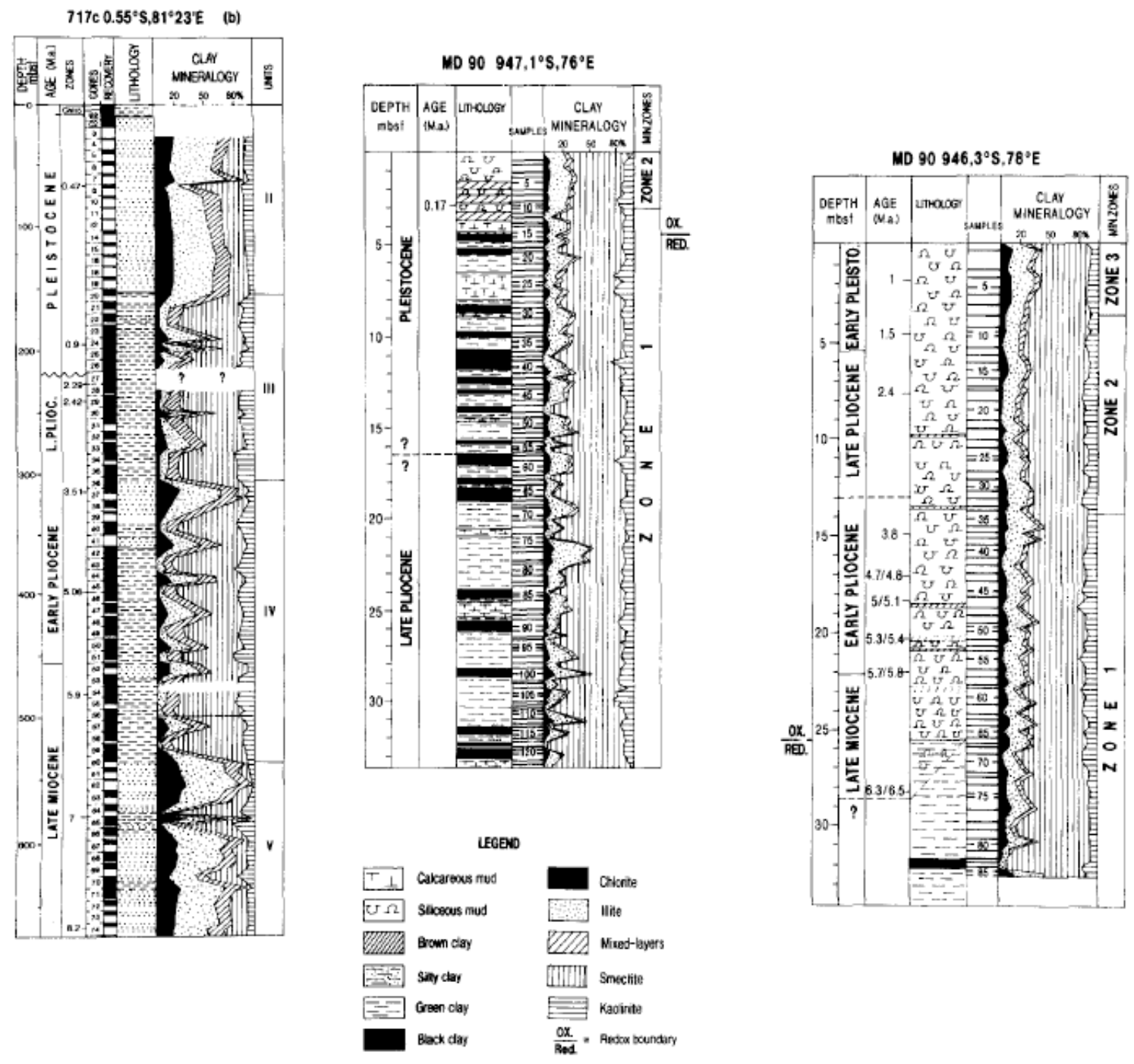

2 Fig. 3. Detailed lithology and clay mineralogy of northern SHIVA cores (MD 90-946 and 3 947) in the Central Indian Basin between $3^{\circ}$ and $1^{\circ} \mathrm{S}$ at $78^{\circ}$ and $76^{\circ} \mathrm{E}$. Age (in Ma) deduced 4 from radiolarian successions. Zonation from clay mineral successions. $O X . / R E D$. = redox 5 boundary; comparison with ODP Hole $717 \mathrm{C}\left(0.5^{\circ} \mathrm{S}\right.$; Bouquillon et al., 1990). 

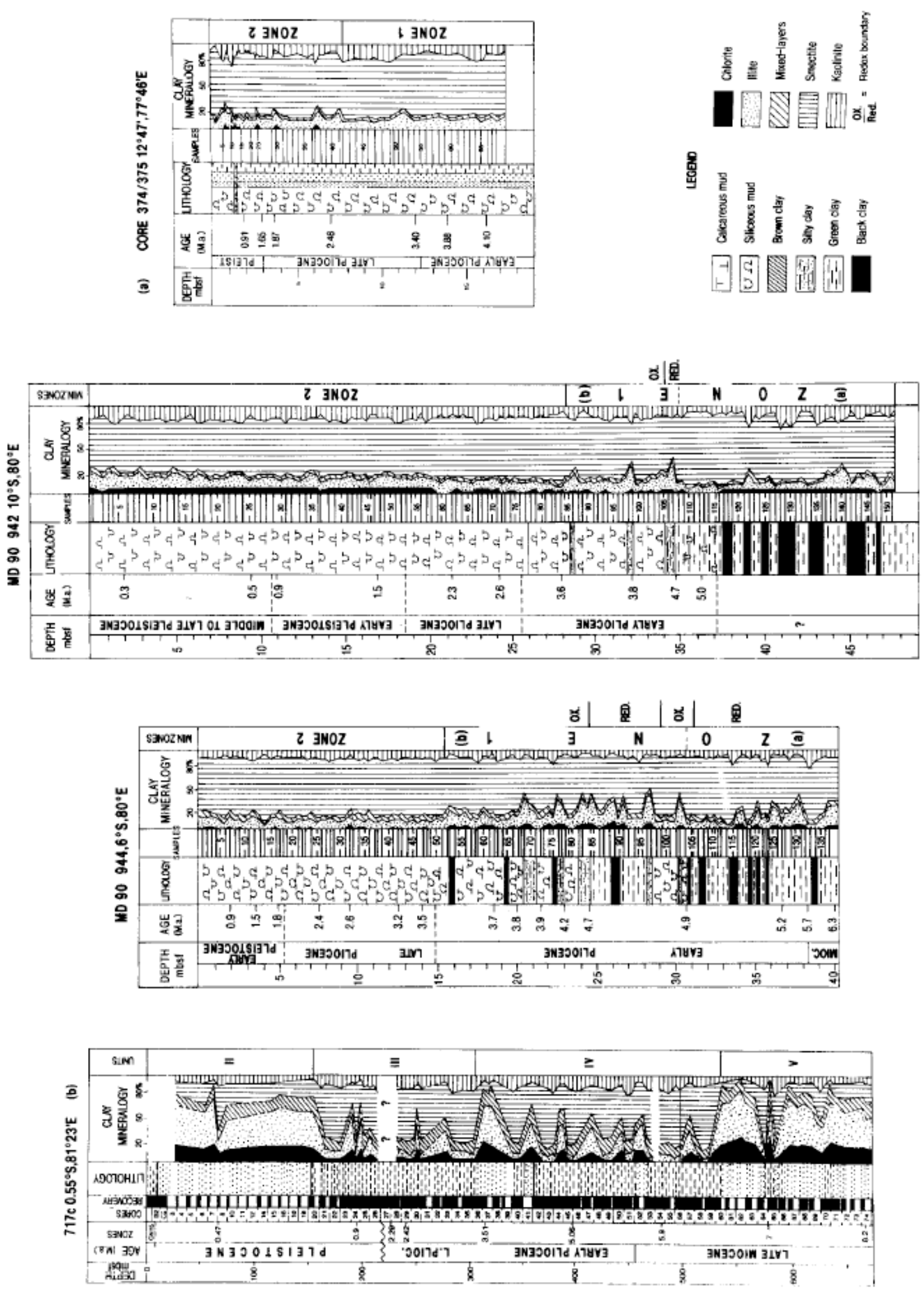

2 Fig. 4. Detailed lithology and clay mineralogy in SHIVA cores $942\left(10^{\circ} \mathrm{S}\right), 944\left(6^{\circ} \mathrm{S}\right)$ and in 3 cores MD $81374 / 375\left(12^{\circ} \mathrm{S}\right.$; Bout, 1991); comparison with ODP Hole $717 \mathrm{C}\left(0.5^{\circ} \mathrm{S}\right.$; 4 Bouquillon et al., 1990). 


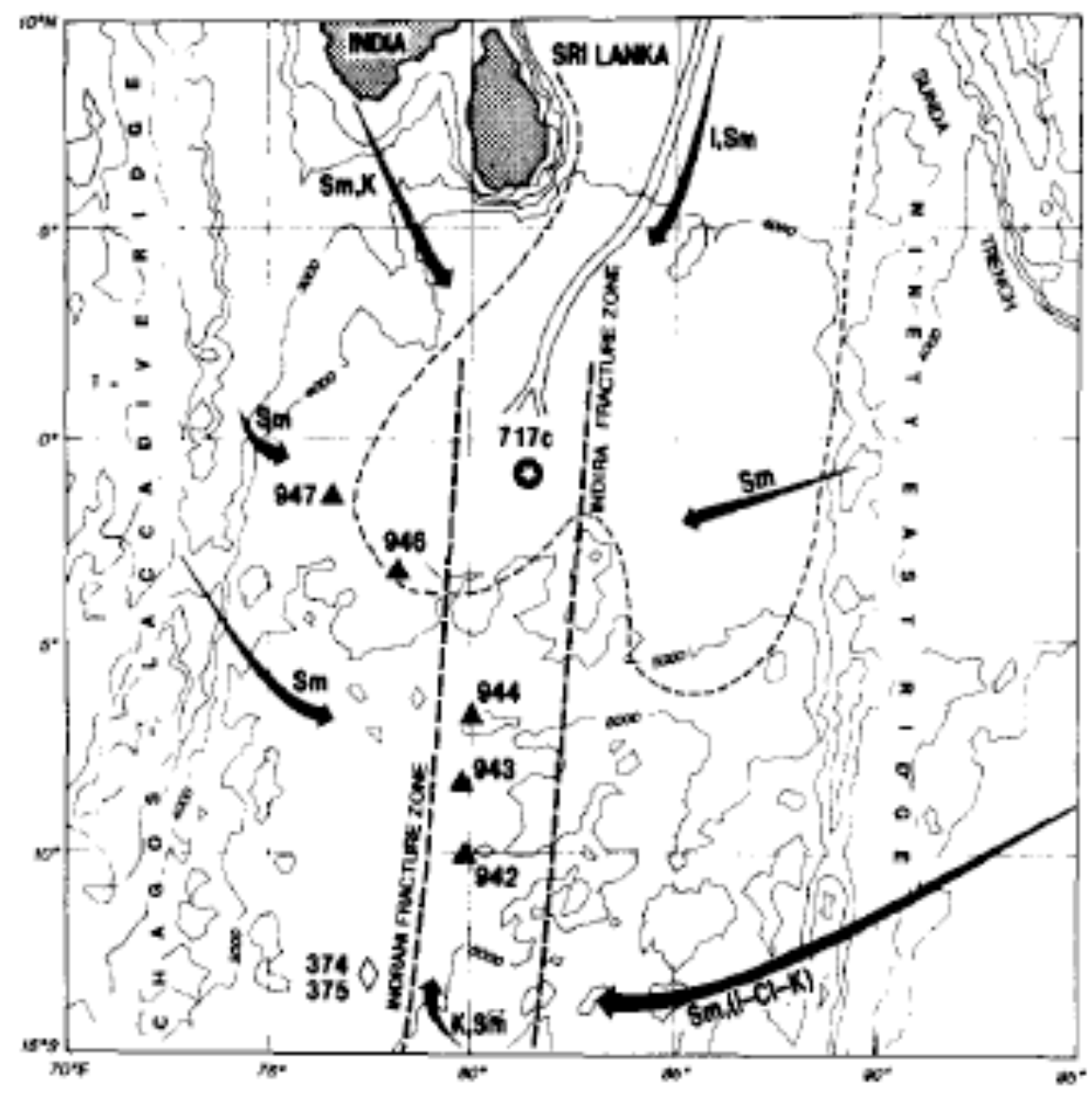

2 Fig. 5. Tentative interpretation of the main clay mineral sources in Central Indian Basin 3 sediments. Map after Cochran (1990); dashed line: Ganges deep-sea fan boundary. 

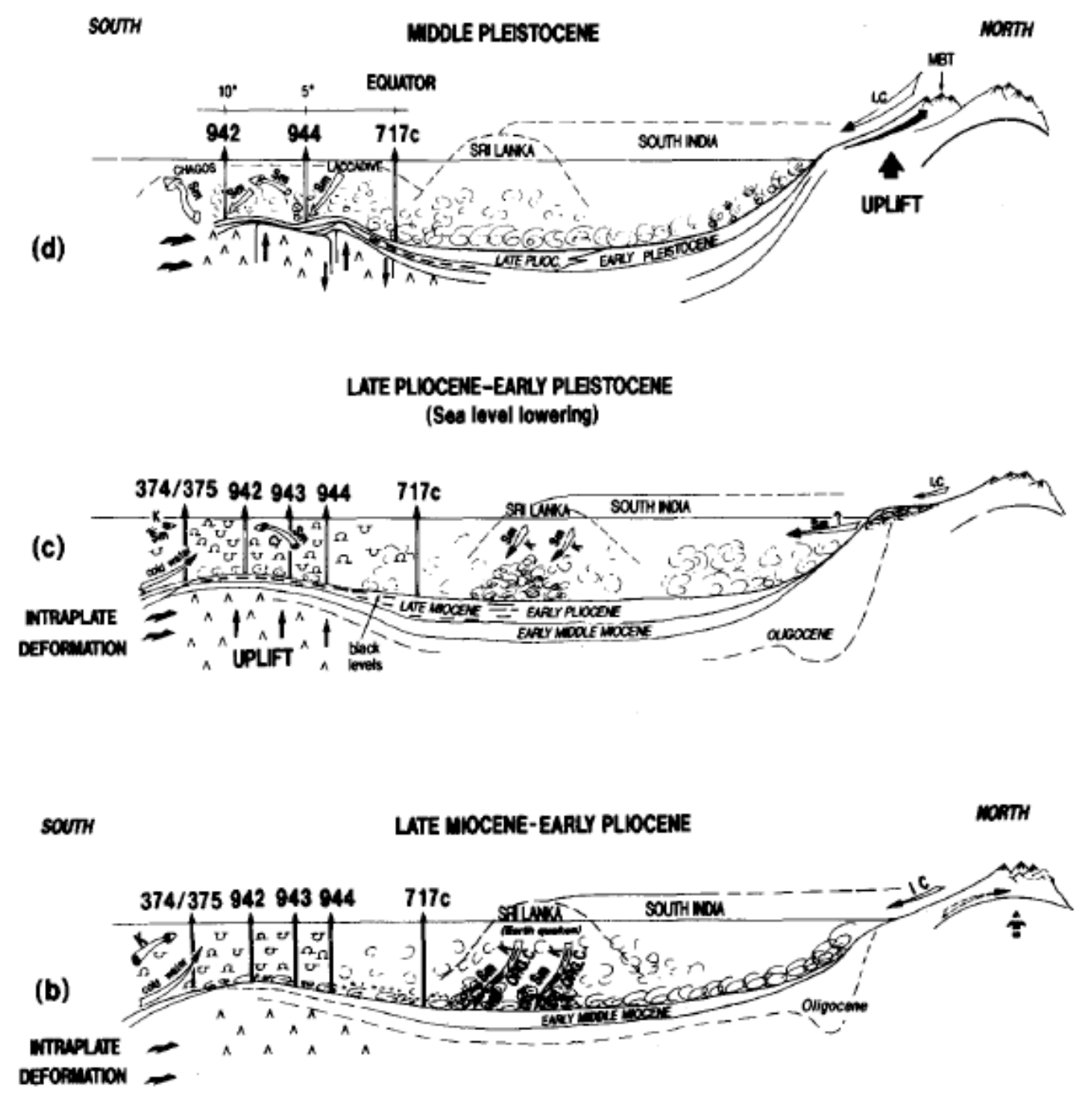

(a)

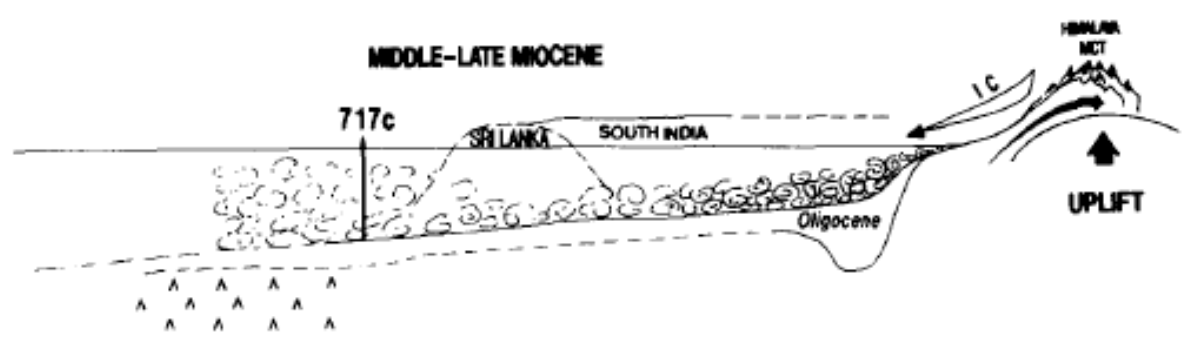

2 Fig. 6. Interpretative sketch of clay mineral fluxes in the northern part of the Central Indian

3 Basin since the upper middle Miocene. 


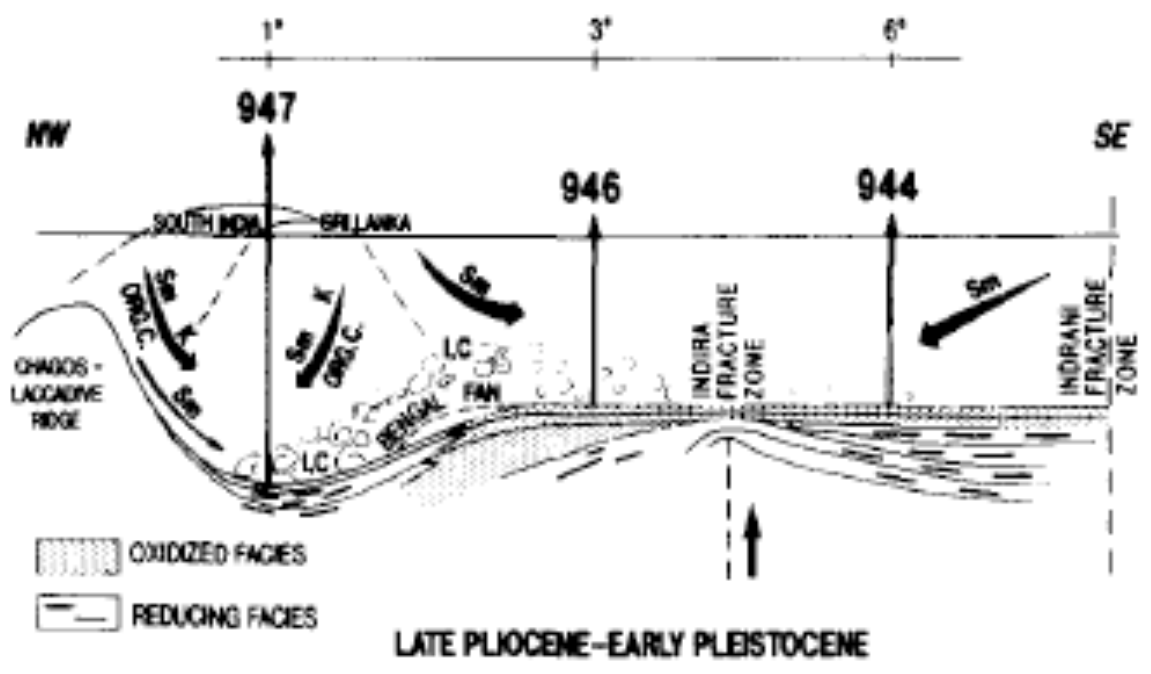

2 Fig. 7. Possible tectonic control of the lithology and clay mineralogy in the equatorial zone of 3 the Central Indian Basin during the late Pliocene. 944-947= SHIVA cores. Vertical arrow $=$ 4 positive intraplate deformations. 
$1 \quad$ Table 1

2 Characteristics of the five very long cores recovered during the MD 90 SHIVA cruise, and of

3 MD cores and ODP hole used for comparison

\begin{tabular}{llllll}
\hline Cores & Latitude & Longitude & $\begin{array}{l}\text { Water depth Penetration } \\
(\mathrm{m})\end{array}$ & Age of oldest sediments \\
\hline MD 90-947 & $0^{\circ} 21^{\circ}$ 'S & $76^{\circ} 37^{\prime} \mathrm{E}$ & 4781 & 34.37 & Late Pliocene \\
MD 90-946 & $0^{\circ} 16^{\prime} \mathrm{S}$ & $7^{\circ} 0 \$ \mathbf{p}^{\prime} \mathrm{E}$ & 4796 & 33.15 & Late Miocene \\
MD-90-944 & $06^{\circ} 39^{\prime} \mathrm{S}$ & $80^{\circ} 07^{\prime} \mathrm{E}$ & 4902 & 40.17 & Late Miocene \\
MD-90-943 & $08^{\circ} 19^{\prime} \mathrm{S}$ & $7^{\circ} 49^{\prime} \mathrm{E}$ & 5249 & 43.75 & Late Miocene \\
MD 90-942 & $10^{\circ} 03$ 'S & $79^{\circ} 48^{\prime} \mathrm{E}$ & 5356 & 48.83 & Late Miocene \\
MD 81-374 & $12^{\circ} 48^{\prime} \mathrm{S}$ & $77^{\circ} 43^{\prime} \mathrm{E}$ & 5332 & 13.50 & Late Pliocene \\
MD 81-375 & $12^{\circ} 47$ 'S & $77^{\circ} 46^{\prime} \mathrm{E}$ & 5279 & 17.50 & Early Pliocene \\
ODP 717C & $0^{\circ} 34^{\prime} \mathrm{S}$ & $81^{\circ} 14^{\prime} \mathrm{E}$ & 4735 & 828.2 & Late Miocene \\
\hline
\end{tabular}

5

6 Table 2

7 Average sedimentation rates (m/m.y.) of Pliocene sediments in the Central Indian Basin. ODP

8 data from Cochran, Stow et al. (1989c)

\begin{tabular}{llll}
\hline & Sites & Early Pliocene & Late Pliocene \\
\hline $\begin{array}{l}\text { North } \\
\text { (Equator) }\end{array}$ & ODP 717c & 58 & 58 \\
& MD 947 & 39 & 39 \\
& MD 946 & 6.5 & 4 \\
& MD 944 & 9.5 & 5.5 \\
& MD 943 & 14 & 4.5 \\
South $\left(10^{\circ} \mathrm{S}\right)$ & MD 942 & 6.5 & 4 \\
\hline
\end{tabular}

9 